\title{
Government control and the value of cash: evidence from listed firms in China
}

\author{
Xinyu Yu ${ }^{1} \cdot$ Ping Wang ${ }^{2}$ \\ Published online: 30 March 2020 \\ () The Author(s) 2020
}

\begin{abstract}
In this paper, we investigate the impact of government control on investors' valuation of cash held by listed firms in China. We find strong and robust evidence that government control leads to a lower value of cash. Further evidence suggests that this negative impact is associated with significant agency costs of political expropriation rather than low financial constraints of the soft-budget effect. Moreover, our extended analyses reveal that the negative impact of government control on the value of cash depends on regional institutional development. In particular, in regions with high institutional development, government control reduces the value of cash, while in areas that are less developed, this negative impact is attenuated to some extent. Overall, our findings shed new light and add a further dimension to the literature, broadening our understanding of the impact of government intervention on the listed firms under its control.
\end{abstract}

Keywords Government control · Value of cash · Political expropriation · China

JEL Classification G30 $\cdot \mathrm{G} 32 \cdot \mathrm{G} 34$

\section{Introduction}

Despite the large wave of privatization that started in the United Kingdom in the 1980s and then spread across the globe during the 1990s, government control over listed firms is still pervasive, especially in the emerging markets in general and the Chinese market in particular (Boubakri et al. 2018). The recent financial crisis, associated with worldwide government intervention, has provoked the debate over government involvement in firms' business decisions, and two competing views emerge. On the one hand, government control can be detrimental to firm value due to its social and political motives, which can lead to inefficiencies (Boycko et al. 1996; Shleifer and Vishny 1997). On the other hand, government connections may bring benefits to firms under its control by providing them with rents and protection such as implicit bailout guarantee, preferential access to credit and

Ping Wang

p.wang.1@bham.ac.uk

1 Keele Business School, Keele University, Keele, Staffordshire, UK

2 Birmingham Business School, University of Birmingham, Birmingham, UK 
government-related contracts (Kornai et al. 2003; Borisova et al. 2015). Given the theoretical benefits and costs of government intervention, there is significant conflicting evidence in the literature on the relationship between government control and firm value (Boubakri et al. 2005; Chen et al. 2009; Liu et al. 2012; Beuselinck et al. 2017; Boubakri et al. 2018).

In this study, we aim to add to this debate by investigating how government control influences firm value through its impact on cash held by firms within the context of China, the world's largest emerging economy. We are particularly interested in China as it offers a suitable setting for studying this topic. China is characterized by government control as the majority of listed firms are former state-owned enterprises (SOEs) that were privatized through the share offering. Although the Chinese government gradually sold its ownership of listed firms to the private sector in recent years, the state still retains as an influential shareholder in many listed firms. For instance, around 54\% of firms in our sample are still ultimately controlled by the government. When the state serves as the controlling shareholder, their socio-economic goals may influence firms' strategic objectives and financial decisions, leading to a different aspect of agency costs, in contrast to private owners.

Cash holdings are one of the most important corporate resources and account for a significant proportion of firm assets. Cash enables firms to finance profitable investment without resorting to external finance, which is especially valuable during the financially constrained period (Opler et al. 1999; Almeida et al. 2004). On the other hand, compared with hard assets, cash reserves can be easily diverted by corporate insiders with little scrutiny for private benefits that come at a cost to outside shareholders (Jensen 1986; Myers and Rajan 1998). Consequently, how market participants value cash held by firms reflects the perceived use of this type of assets, which largely depends on corporate financial constraints and agency costs (Faulkender and Wang 2006; Pinkowitz et al. 2006; Dittmar and Mahrt-Smith 2007; Denis and Sibilkov 2009). However, one potential and important determinant that may affect investors' valuation on cash is government control, which is not well explored in the literature, especially the way(s) in which government control may influence the valuation of cash and how institutional development may moderate the association between government control and the value of cash. These are the questions that motivate the present study.

This paper is related to the study of Megginson et al. (2014), who examine the impact of state ownership on the level, as well as the value, of cash for listed firms in China. They demonstrate, in particular, that the value of cash decreases with state ownership. Our paper extends beyond their work in several ways. First, Megginson et al. (2014) focus on state ownership measured by the percentage of shares owned by the government. However, this measurement may underestimate the controlling power of the state, since many state agencies and SOEs exert control indirectly through control rights. Bortolotti and Faccio (2009) suggest that ultimate control can provide a better picture of government power on firms under its control. Therefore, in this paper, we chase up the identity of the ultimate controlling shareholders and use a number of measurements to proxy ultimate control by the government, as opposed to direct ownership. Second, Megginson et al. (2014) maintain that the value-destroying effect is due to the soft-budget constraints inherited in state ownership without empirically testing for this premise. The current research seeks to discover the mechanisms underlying such relationship by analyzing and distinguishing two possible channels: the agency costs of political expropriation and the financial constraints of the soft-budget effect.

Third, the present paper explores how the relationship between government control and the value of cash may be conditional on the quality of the institutional environment. As to the benefits and costs of government control, the extant literature based on 
the cross-country setting is rather mixed, perhaps partially due to the omitted-variable and aggregation biases present in cross-country studies. In the case of China, following almost four decades of the economic reform, the disparity of institutional development and great heterogeneity in legal systems across various regions in the country have become increasingly significant (Chen and Zheng 2008). Given the country's large size and geographical diversity, it thus offers a natural experiment to explore, within a single-country setting, how regional differences in institutional development may facilitate the role of government control through investors' valuations on corporate cash reserves in listed firms. Therefore, China is an ideal setting to test the hypotheses proposed in this study.

Using an unbalanced panel consisting of 19,340 firm-year observations from 2430 unique listed firms in China over the period 2003-2015, we find that government control reduces the value of cash. Economically, an extra unit (RMB) of cash held in a state-controlled firm is, on average, valued at 0.25 (RMB) less than that is held in a privately controlled firm. The result is robust to a battery of additional tests, including year, firm and industry fixed effects, alternative measures of government control and expected change in cash, and is insensitive to the inclusion of a set of corporate governance variables. Furthermore, our result remains valid after the endogeneity concern is addressed, based on various approaches, such as using lagged variables to proxy for government control, a propensityscore matched (PSM) sample and focusing on the firms that have gone through the change from state control to private control during the sample period.

Moreover, our evidence suggests that the channel through which government control lowers the value of cash is mainly due to the agency costs of political expropriation rather than the financial constraints of the soft-budget effect. Specifically, our results reveal that cash is more likely to be disgorged in investment with few growth opportunities (Tobin's Q), and is used less in innovation activities, such as research and development (R\&D), in firms under government control than their counterparts under private control. This implies that cash holdings in government-controlled firms are invested in projects mostly for political considerations. The market, accordingly, discounts the value of cash significantly in these firms. However, we find no evidence of the financial constraints of the soft-budget effect. Government control neither alleviates financial constraints nor enhances external financing abilities in listed firms under its control.

Lastly, we find that the association between government control and the value of cash is conditional on the level of the institutional quality across the regions within the country. Specifically, we find that the negative impact of government control is somewhat attenuated in regions with low market development and poor government quality. The evidence appears to support the "helping hand" of the government that has, indeed, adopted a series of subsidization programs in order to tackle the regional disparity in recent years. Therefore, the costs of government control appear to be alleviated by the benefits received in these regions.

Our paper contributes to the literature in several ways. First, this study adds to the recent debate over the effect of government control on firm value (Chen et al. 2009; Liu et al. 2012; Beuselinck et al. 2017; Boubakri et al. 2018), by focusing on the investors' valuation of cash. First, we focus on the ultimate control by the government, a measurement that avoids the underestimation problem of state direct ownership, which is important for Chinese listed firms because the state and related agencies exert control indirectly over listed firms. Therefore, it complements the findings of Pinkowitz et al. (2006) and Dittmar and Mahrt-Smith (2007) on corporate governance and extends their arguments to government control, one of the most important characteristics in transitional economies. More importantly, our study helps facilitate a better understanding of the mechanisms that underlie the 
relationship that we document by demonstrating that the value-destroying effect is mainly due to the agency costs of political expropriation associated with their socio-economic objectives. This is consistent with recent evidence that government ownership does not necessarily decrease the cost of capital or enhance financing ability (Ben-Nasr et al. 2012; Firth et al. 2012; Borisova et al. 2015; Jaslowitzer et al. 2016).

Second, our paper adds to the literature relating to the institutional quality on firms' financing decisions by providing evidence of their conditional effect on the relationship between government control and the value of cash. Prior research based on a cross-country study provides mixed evidence regarding the benefits and costs of government ownership (Guedhami et al. 2009; Beuselinck et al. 2017; Boubakri et al. 2018). We extend this literature by focusing on a single-country setting that can avoid some potential issues encountered in cross-country studies. Our findings shed new insights that broaden our understanding of the role of the government. In particular, firms located in regions with less developed institutions benefit more from the government owing to its series of development programs, and therefore the negative effect of government control due to political objectives is mitigated to some extent.

The remainder of the paper is organized as follows. In the next section we review the relevant literature and develops the hypothesis, with research design presented in Sect. 3. Section 4 includes the main results and robustness tests. Section 5 discusses the role of institutional development, and Sect. 6 concludes the paper.

\section{Literature and hypothesis}

\subsection{The value of cash holdings}

Cash is an important and valuable asset to firms, especially when other sources of finance, such as cash flows, debts and equity issuances, are insufficient to finance profitable investment. Liquid assets enable firms to hedge against the changes in growth opportunities and negative cash flow shocks (Opler et al. 1999; Almeida et al. 2004; Acharya et al. 2007). Cash is especially important for financially constrained firms, as it can help constrained firms to undertake profitable projects that might otherwise be bypassed. Consistent with this view, studies find that cash holdings are more valuable to investors for firms with high financial constraints (Faulkender and Wang 2006; Denis and Sibilkov 2009).

However, one severe cost of cash reserves is related to agency problems. Although many kinds of assets can be turned into private benefits, cash reserves are especially at risk. Compared with hard assets, such as property, plant, equipment (PPE) and inventories, cash holdings can be easily extracted by self-interested managers and controlling shareholders to pursue their personal benefits at the expense of minority shareholders' interests (Jensen and Meckling 1976; Myers and Rajan 1998). When investors anticipate that corporate insiders may use cash holdings for private benefits, they would attach a lower value to cash holdings in such firms, leading to a substantial value destruction pertaining to agency problems. In line with the argument, Pinkowitz et al. (2006) find that cash is worth much lower in countries with lower investor protection. Using management entrenchment and shareholder activism as proxies for corporate governance, Dittmar and Mahrt-Smith (2007) show that the marginal value of cash, as well as the value of excess cash, is higher in well governed firms than in poorly governed firms. Lee and Lee (2009) find that the negative 
relationship between firm value and cash holdings is more pronounced in poorly governed firms, measured by board independence, board size and managerial entrenchment.

\subsection{Government control}

In an agency framework, government ownership is associated with political intervention and inefficiency. The "grabbing hands" of the government described by Shleifer and Vishny (1998) show how firms' resources may be diverted to achieve political objectives or social welfare, such as maintaining a high level of employment and preserving social stability, rather than shareholders' wealth maximization (Boycko et al. 1996; Shleifer and Vishny 1997). In addition, the agency costs of government control may exist in another way, because managers of government-controlled firms are typically entrenched and may exploit their positions and collude with the government to expropriate corporate resources for their own personal agendas and political advantages (Shleifer and Vishny 1994; Shleifer 1998). Therefore, governance mechanisms are poor, and the agency costs of managers are severe in government-controlled firms (Vickers and Yarrow 1991). In line with this view, empirical studies find that government ownership leads to investment inefficiency and poor performance in the cross-country setting (Megginson and Netter 2001; Boubakri et al. 2005, 2008; Jaslowitzer et al. 2016; Chen et al. 2017) and in China (Chen et al. 2008, 2011b; Firth et al. 2012). If the high agency costs associated with political objectives exist, it may inversely affect the value of cash held by firms due to the ineffective use of cash perceived by investors.

Another strand of research documents that firms with government involvement are less subject to the threat of financial distress due to the implicit government support and the ineffective discipline imposed by market investors (Megginson and Netter 2001). Compared with private owners, the government can deploy fiscal means, credits and indirect support whenever an SOE falls into financial distress, and firms under its control are usually subject to soft-budget constraints. Earlier empirical studies have found that firms with more government ownership receive a disproportionally large share of credit and a low cost of capital (Charumilind et al. 2006; Borisova and Megginson 2011). However, recent evidence in the literature casts doubt on the benefits of government ownership on corporate financing ability. For example, Ben-Nasr et al. (2012) maintain that government ownership is associated with higher cost of equity due to the agency risk. Similarly, Borisova et al. (2015) document that government ownership increases the cost of debt in normal periods, consistent with state-induced investment distortions. Jaslowitzer et al. (2016) further show that government ownership does not mitigate firms' financial constraints. Whether firms under government control are subject to low levels of financial constrains is still under academic debate. In terms of China, prior literature has shown that SOEs receive a large share of credits (Cull and Xu 2003; Gordon and Li 2003) and face a lower degree of financial constraints than non-state-owned firms (Guariglia et al. 2011), whereas recent literature finds no such evidence (Firth et al. 2012; Lin and Bo 2012). Importantly, large cash holdings enable firms to finance investment projects without resorting to external finance (Faulkender and Wang, 2006). Therefore, if government control is associated with low financial constraints, the marginal value of cash should be lower in firms under government control than those under private control. 
Taken together, both the agency costs of political expropriation and the financial constraints of the soft-budget effect imply a negative impact of government control on the value of cash, which leads to our first testable hypothesis, below.

H1: The value of cash is lower in firms controlled by the government than in firms controlled by private owners.

\subsection{The role of institutional development}

The level of institutional development has been considered to be one of the important factors that may affect the impact of government control on corporate policies (La Porta et al. 1999, 2002). The extant literature is largely based on the evidence within the cross-country context, although the results are far from conclusive. For example, Borisova et al. (2012) show that government ownership improves (deteriorates) corporate governance in common-law (civillaw) countries, suggesting the relative benefits of government ownership in regions with better investor protection. Similar findings are also reported by Beuselinck et al. (2017) and Boubakri et al. (2018). Another strand of scholarship finds, on the contrary, that firms benefit from close connections to the state and politicians in both developed and developing countries, and the benefits are found to be generally more pronounced in markets with relatively low institutional development and weak legal systems (Faccio 2006; Boubakri et al. 2012, 2013b). However, what is unclear in the extant literature is how government control in corporate decisions may depend on the institutional development within a single-country setting. Given the issues encountered in a cross-country setting, such as an inability to control for the variation in culture and policy changes, this is another research gap that we intend to address in this study.

In China, fiscal decentralization from central to local governments-since the economic reform began in 1978- has created well documented regional imbalances across its 31 provinces, autonomous regions and municipalities, with the coastal provinces being much advanced than the interior provinces. For example, the average gross regional product (GRP) per capita was RMB 76,549.38 for the most developed province (Beijing) and RMB 13,927.39 for the less developed western region (Guizhou) during our sample period. The vast regional disparities are primarily attributed to development policies implemented by the government, which were in favor of the coastal areas in the earlier stage of the reform, and which have accelerated since the early 1990s. In order to improve regional development and reduce regional differences, the government plays as a more instrumental role in introducing a series of development programs, such as the western development strategy launched in late 1990; the north-east revival strategy in 2003; and the rise of central China in more recent years, which help to enhance economic development in less developed provinces (Chen and Zheng 2008). Thus, it is likely that firms controlled by the government in less developed regions will receive more economic rents due to the favorable shift of financing contracts and financial subsidies from the state, which may alleviate the negative impact of investors' valuation on cash in regions with low institutional development and weak legal systems. Therefore, our second testable hypothesis is stated below.

H2: The negative impact of government control on the value of cash is attenuated in regions with less developed institutions. 


\section{Research design}

\subsection{Sample}

Our sample includes all A-share firms listed on the Shenzhen Stock Exchange (SZSE) and Shanghai Stock Exchange (SHSE) during the period 2003-2015. The sample period starts in 2003, which is the year when Chinese listed firms were required to disclose their controlling shareholders in annual reports, the information required to identify whether a firm is controlled by the state or by a private owner. Financial data is extracted from the China Stock Market and Accounting Research (CSMAR) database. We follow customary practices to exclude firms in the financial industry. We then delete firm-year observations with missing stock returns and negative equities and net assets (i.e. total assets minus cash and cash equivalents). All firms included in the sample have an ultimate controlling shareholder, either the state or a private owner. Firm-year observations with no or multiple types of ultimate controlling shareholders are also excluded. ${ }^{1}$ An included firm is required to have more than two consecutive years of data. Our final unbalanced panel consists of 19,340 firm-year observations with 2430 unique firms.

\subsection{Measurement of government control}

Government control is measured according to the ultimate control right, as opposed to direct government ownership. Since the state can exert control indirectly through control rights, using ultimate control can better capture the extent of state influence on firms' financial decisions than ownership (Bortolotti and Faccio 2009). For each year, the type of ultimate controlling shareholder is identified from annual reports. A firm is classified as government-controlled if it is ultimately controlled by the state or state agencies, such as a state asset-management bureau, or a state-owned enterprise. Otherwise, it is classified as a firm controlled by private owners. ${ }^{2}$ We define a dummy variable, $G O V$, which is equal to one for government-controlled firms, and zero for privately controlled firms.

In the robustness test, three alternative measures of government control are constructed in order to further determine the effective control of the state at the ultimate level. The first and second alternative measures, GOV1 and GOV2, are defined as dummy variables taking the value of one if the government's ultimate control right is greater than $10 \%$ and $20 \%$ (Claessens et al. 2002), respectively, and zero otherwise, and the third alternative measure, following Boubakri et al. (2018), is a continuous variable, GOV_cont, defined as the state's ultimate control rights in government-controlled firms, which is determined by the weakest link along the control chain, and zero for privately controlled firms.

\footnotetext{
${ }^{1} 268$ firm-year observations were excluded due to no or multiple types of ultimate controlling shareholders.

${ }^{2}$ Privately controlled firms include a few firms controlled by foreign investors.
} 


\subsection{Model specification}

We investigate the effect of government control on the value of cash based on a model akin to that of Faulkender and Wang $(2006)^{3}$ :

$$
\begin{aligned}
r_{i, t}-R_{i, t}^{B}= & \beta_{0}+\beta_{1} \Delta C A S H_{i, t}+\beta_{2} \Delta C A S H_{i, t} \times G O V_{i, t}+\beta_{3} \Delta E B I T_{i, t}+\beta_{4} \Delta N A_{i, t} \\
& +\beta_{5} \Delta I N T_{i, t}+\beta_{6} \Delta D I V_{i, t}+\beta_{7} C A S H_{i, t-1}+\beta_{8} M L E V_{i, t}+\beta_{9} N F_{i, t} \\
& +\beta_{10} C A S H_{i, t-1} \times \Delta C A S H_{i, t}+\beta_{11} M_{L E V} \times \Delta C A S H_{i, t}+\beta_{12} G_{i, t} O V_{i, t} \\
& +\varepsilon_{i, t}
\end{aligned}
$$

where the dependent variable, $r_{i, t}-R_{i, t}^{B}$, is the change in firm value, measured by excess stock return, calculated as the stock return for firm $i$ minus the return of stock $i$ 's benchmark portfolio over fiscal year $t$. The benchmark portfolios are 25 Fama and French portfolios formed on size and book-to-market ratio. ${ }^{4} \Delta$ refers to the change of a variable between two consecutive years. $\mathrm{CASH}$ is cash and cash equivalents. Similar to Faulkender and Wang (2006), we first use the realized change in cash, on the assumption that the expected change is zero. Three alternative definitions of expected change in cash are used in the robustness test. $G O V$ represents government control. Control variables include earnings before interest and taxes $(E B I T)$, net assets $(N A)$, interest expenses (INT), common dividends paid (DIV), total debts divided by the market value of equity $(M L E V)$ and net equity and debt financing $(N F)$. All variables except for $G O V$ and $M L E V$ are deflated by the one-year lagged market value of equity. The full variable description is shown in Table 1.

Our variables of interest are the change in cash $(\triangle C A S H)$ and its interaction with government control $(\triangle C A S H \times G O V)$. Since excess stock return and the change in cash are both normalized by the previous year's market value of equity, the coefficient on $\triangle C A S H$ measures the change in shareholder value following one unit change in cash held by the firm (i.e. the marginal value of cash). The effect of government control on the value of cash is determined by the coefficient on the interaction between the change in cash and government control $\left(\beta_{2}\right)$. According to our first hypothesis, an extra unit of cash added to the firm will result in a smaller increase in market value if the firm is controlled by the state, which predicts a negative coefficient on $\beta_{2}$.

\subsection{Descriptive statistics}

Table 2 reports the summary statistics of the main variables. As shown in Panel A, the mean of government control is $52.4 \%$, suggesting that over half of the listed firms in China are ultimately controlled by the state during our sample period. This figure is much lower than what is reported in prior studies (Chen et al. 2011b; Firth et al. 2012). This difference is due to the increase in newly listed privately controlled firms, especially from 2008 onwards. In addition, the distributional characteristics of the control variables in our model are similar to the US-based data (Faulkender and Wang 2006; Dittmar and Mahrt-Smith 2007; Chou and Feng 2019) and China-based data (Megginson et al. 2014; Xu et al. 2016).

\footnotetext{
3 The change in $R \& D$ expenses is excluded from the equation due to missing data in the early sample period.

4 Since there are no Fama and French portfolios available for Chinese stock markets, we follow Fama and French (1993) and classify firms into one of 25 portfolios based on the intersections between the market value of equity and book-to-market ratio quintiles independently at the beginning of each year.
} 
Table 1 Variable definition

\begin{tabular}{|c|c|}
\hline Variable & Definition \\
\hline GOV & $\begin{array}{l}\text { A dummy variable set to one if the ultimate controller is a government institution, and } \\
\text { zero otherwise }\end{array}$ \\
\hline GOV1 & $\begin{array}{l}\text { A dummy variable set to one if a government institution ultimately controls the firm at } \\
\text { above } 10 \% \text { control rights, and zero otherwise }\end{array}$ \\
\hline GOV2 & $\begin{array}{l}\text { A dummy variable set to one if a government institution ultimately controls the firm at } \\
\text { above } 20 \% \text { control rights, and zero otherwise }\end{array}$ \\
\hline GOV_cont & $\begin{array}{l}\text { Government's ultimate control rights in government-controlled firms, and zero in pri- } \\
\text { vately controlled firms }\end{array}$ \\
\hline State ownership & The percentage of legally defined state-owned shares \\
\hline Transfer & $\begin{array}{l}\text { A dummy variable set to one in year when firm is transferred to private owners and after- } \\
\text { wards, and zero in years preceding the transformation }\end{array}$ \\
\hline$r-R^{B}$ & $\begin{array}{l}\text { Excess stock return, where } r \text { is the stock return and } R^{B} \text { is the corresponding benchmark } \\
\text { portfolio return in the same year }\end{array}$ \\
\hline CASH & Cash and cash equivalents \\
\hline$M V E$ & The market value of equity \\
\hline EBIT & Earnings before interest and taxes \\
\hline$N A$ & Net assets, defined as total assets minus cash and cash equivalents \\
\hline INT & Interest expenses \\
\hline DIV & Cash dividends \\
\hline$M L E V$ & Market leverage, defined as total debts divided by the market value of assets \\
\hline$N F$ & Net financing, defined as the sum of net proceeds from equity and debt issuance \\
\hline$M O W N$ & The percentage of shares owned by managers \\
\hline INST & The percentage of shares owned by domestic mutual funds and QFII \\
\hline EXCESS & The ratio of control rights to cash-flow rights by the ultimate controllers \\
\hline$A N A C O V$ & The natural logarithm of one plus the number of analysts following the firm \\
\hline$I N C R \_I N V$ & $\begin{array}{l}\text { Increase in investment, defined as a dummy variable set to one if a firm increases invest- } \\
\text { ment in the next year, and zero otherwise; Investment is measured by capital expendi- } \\
\text { ture or the sum of capital expenditure and acquisitions }\end{array}$ \\
\hline$I N C R \_R D$ & $\begin{array}{l}\text { Increase in } R \& D \text {, defined as a dummy variable set to one if a firm increases research and } \\
\text { development expenses in the next year, and zero otherwise }\end{array}$ \\
\hline$Q$ & $\begin{array}{l}\text { Tobin's q, defined as the market value of equity plus liabilities divided by total assets } \\
\text { minus intangible assets and goodwill }\end{array}$ \\
\hline$S I Z E$ & The natural logarithm of total assets adjusted using the CPI deflator \\
\hline$C F$ & Operating cash flow, defined as net cash flow from operating activities \\
\hline$B L E V$ & Book leverage, defined as total debts divided by the book value of total assets \\
\hline$D I V$ & A dummy variable set to one if the firm pays out dividends, and zero otherwise \\
\hline$S G$ & The growth rate of sales \\
\hline$R O A$ & Earnings before interest and taxes divided by total assets \\
\hline$M B$ & $\begin{array}{l}\text { Market to book ratio, defined as the market value of equity plus total liabilities divided by } \\
\text { the book value of assets }\end{array}$ \\
\hline CAPEX & $\begin{array}{l}\text { Capital expenditures, defined as cash paid to acquire and construct fixed assets, intangible } \\
\text { assets and other long-term assets minus the cash received from the disposals of fixed } \\
\text { assets, intangible assets and other long-term assets }\end{array}$ \\
\hline$N W C$ & $\begin{array}{l}\text { Net working capital, defined as current assets minus cash and cash equivalents minus } \\
\text { current liabilities }\end{array}$ \\
\hline$S T D$ & Short-term debts \\
\hline$G E I$ & Gross equity issued, defined as the amount of proceeds from equity issues \\
\hline
\end{tabular}


Table 1 (continued)

\begin{tabular}{|c|c|}
\hline Variable & Definition \\
\hline$N D I$ & $\begin{array}{l}\text { Net debt issued, defined as the amount of cash received from issuing bonds or obtaining } \\
\text { bank loans minus repayments }\end{array}$ \\
\hline$A G E$ & The natural logarithm of one plus the number of years after the initial public offering \\
\hline$M K T$ & The composite NERI index of marketization at the province level \\
\hline$B A N K$ & The NERI index of banking liberalization at the province level \\
\hline GOVT & The NERI index of government decentralization in the economy at the province level \\
\hline FISC & $\begin{array}{l}\text { The government fiscal condition, measured by local government fiscal revenue divided } \\
\text { fiscal expenditure at the province level }\end{array}$ \\
\hline$N A D M$ & $\begin{array}{l}\text { The government non-arbitrary revenue, measured by the percentage of local government } \\
\text { non-administrative revenue at the province level }\end{array}$ \\
\hline$E M P$ & The condition of employment, measured by the employment rate at the province level \\
\hline$G R P$ & The natural logarithm of gross regional product at the province level \\
\hline GRPGTH & The growth rate of gross regional product at the province level \\
\hline
\end{tabular}

We split firms into those controlled by the state and by private owners, as shown in Panel $\mathrm{B}$, where t- and Wilcoxon-tests are employed to compare the mean and median difference of each variable between the two groups, respectively. The government-controlled firms, on average, have a relatively higher figure than privately controlled firms for all control variables relating to the value of cash, including the change in cash, change in profitability, change in interest expenses and market leverage.

Panel C displays the distribution of government control over the sample period. It is worth noting that the percentage of shares owned directly by the state declines significantly from $36.4 \%$ in 2003 to only $2.8 \%$ in 2015 , as shown in Panel C. However, the government still retains substantial control of privatized firms as the ultimate controlling shareholder $(52.4 \%$ on average), or through ultimate control rights (21.8\% on average). Therefore, it is highly likely that using state ownership as a proxy for government control may underestimate the influential power of government on firms under its control. All continuous financial variables are winsorized at the top and bottom $1 \%$ level to minimize the effect of outliers.

\section{Main results}

\subsection{Government control and the value of cash}

Table 3 reports the estimation results in Panel A and the marginal value of cash calculated for an average firm in Panel B. ${ }^{5}$ The baseline regression, similar to Faulkender and Wang (2006), without government control included, is reported in column 1 of Panel A. The coefficient estimate shows that an extra unit (RMB) of cash increases shareholder wealth

\footnotetext{
${ }^{5}$ Panel $\mathrm{B}$ of Table 3 shows the marginal value of cash for an average firm in our sample. It is calculated based on the coefficient estimates from Panel A, or more specifically, it equals the coefficient on the change in cash plus the sample means of all variables that interact with the change in cash times the corresponding interaction coefficients. For example, in the baseline regression, the mean firm has cash holdings of $19.8 \%$ of lagged market equity and a market leverage of $13.9 \%$. The marginal value of cash is calculated as 1.618 $-1.472 \times 0.198-2.352 \times 0.139=1.00$.
} 
Table 2 Descriptive statistics of main variables

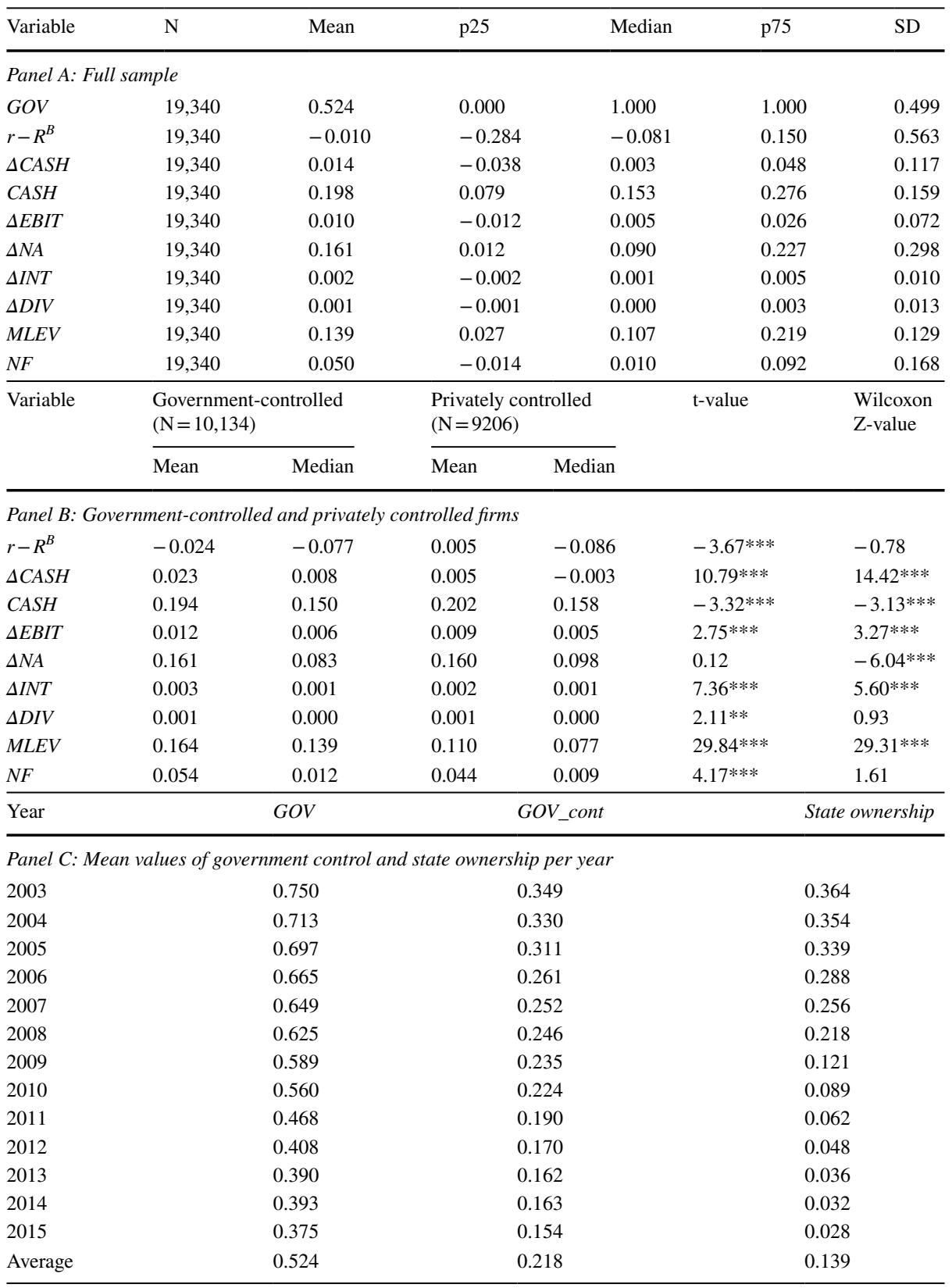

This table provides summary statistics of key variables for the full sample in Panel A and for the government-controlled and privately controlled firms in Panel B and mean values of government control and state ownership per year in Panel C. $\Delta$ indicates the change from the previous year. All variables except $M L E \mathrm{~V}$ are deflated by the lagged market value of equity $(M V E)$. The definitions of all variables are in Table 1 . The t- and Wilcoxon-tests are employed to compare the mean and median difference of each variable between government-controlled firms and privately controlled firms in Panel B $* * *, * *$ and $*$ denote significance at the $1 \%, 5 \%$, and $10 \%$ levels, respectively 
by RMB 1.62 if a firm has no cash holdings or debts. As reported in column 1 of Panel B, on average, the value of an additional RMB of cash holdings to shareholders in the mean firm is RMB 1.00. Our result is very similar to what is found by Faulkender and Wang (2006), who report a slightly lower marginal value of cash to shareholders of US \$0.94. One potential reason for the difference is that firms in China, as in many emerging countries, regard financial constraints as one of their primary obstacles to funding profitable investments, given the country's high speed of development (Cull et al. 2015). Therefore, cash is more valuable to shareholders in China than in the US due to operational considerations and precautionary motives (Faulkender and Wang 2006; Denis and Sibilkov 2009).

All control variables are significant with expected signs, consistent with the literature (Faulkender and Wang 2006; Dittmar and Mahrt-Smith 2007). Specifically, we find that the excess stock return is positively correlated with the change in profitability, the change in net assets, the change in interest expenses, the change in dividends and lagged cash holdings; and it is negatively associated with market leverage. The coefficients on the change in cash interacted with cash holdings and with market leverage are both significantly negative, supporting the view that the value of cash decreases as a firm holds more cash and debts. The results are plausible, since firms with little or no cash reserves tend to have costly access to external finance, thereby benefiting the most from additional liquid assets. Similarly, since the likelihood of default increases with the level of debts, the value of cash decreases with debts.

In column 2, government control, measured by government dummy, and its interaction with the change in cash are included. The coefficient on the interaction term $\triangle C A S H \times G O V$ is negative and statistically significant. Economically, an extra unit (RMB) of cash held in an average firm controlled by the government is valued RMB 0.25 less than that is held in a privately controlled firm. To address the concern of time-specific and time-invariant firm- or industry- level factors, we run the fixed effects regression controlling for year and industry or firm heterogeneity, as shown in columns 3 and 4, respectively. The results indicate clearly that our main finding continues to hold.

We then partition our sample into government-controlled and privately controlled firms, and conduct a subsample analysis as a comparison. The regression results and the difference of government- and privately controlled firms are shown in columns 5-7. The coefficient on $\triangle C A S H$ is 1.48 and 1.91 in firms controlled by the government and by private owners, respectively. The difference $(-0.43)$ is statistically significant at the $5 \%$ level. Moreover, the significance and magnitude of the control variables vary across the two subsamples. Specifically, firm value, measured as the excess stock return, is less positively affected by a change in profitability or change in net assets and is more positively affected by a change in dividends and cash holdings in state-controlled firms compared to privately controlled ones. The negative effect of market leverage on the excess stock return is weaker in state-controlled firms than in privately controlled firms. Interestingly, the value of cash decreases less as market leverage increases in state-controlled firms than in privately controlled firms. One possible explanation is that the likelihood of default is low in firms controlled by the state due to the implicit bailout guarantee during distress.

Overall, the evidence presented in this section is in line with our first hypothesis, suggesting that the value of cash is discounted by investors for firms under the government control. 


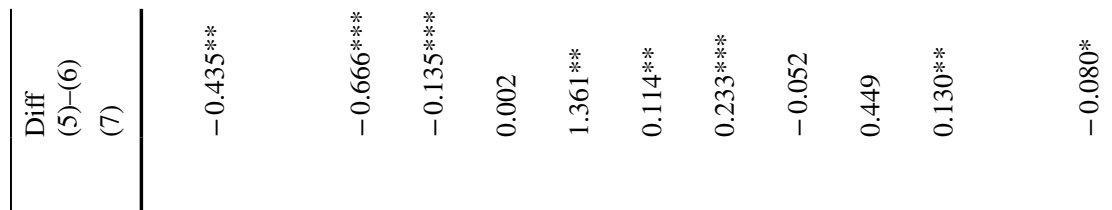

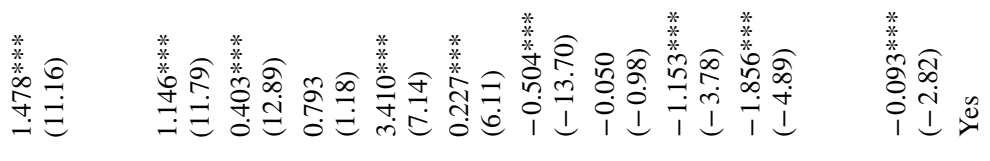

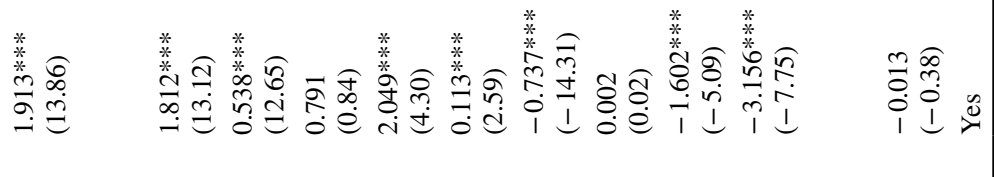

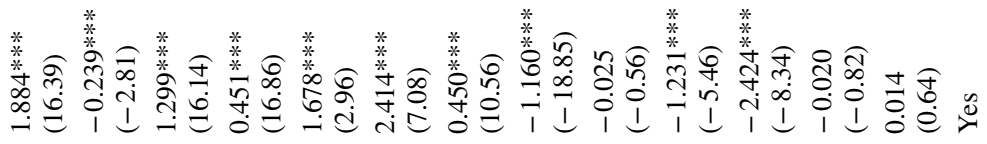

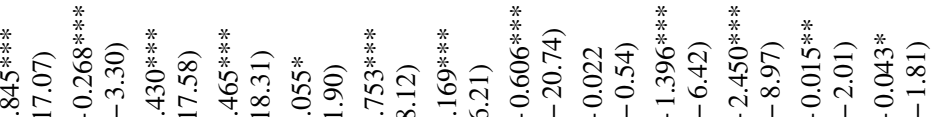

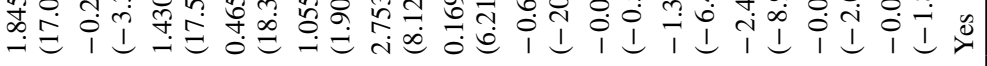

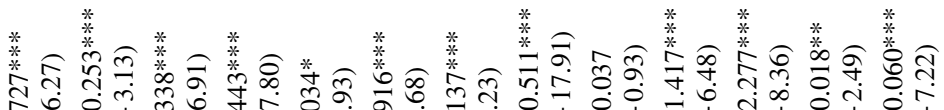

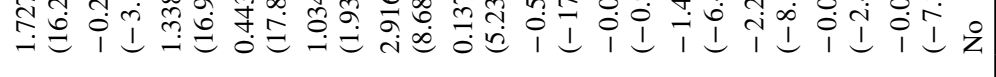

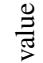

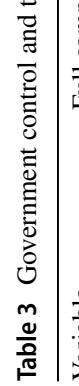

$$
\begin{aligned}
& \widehat{\imath}
\end{aligned}
$$

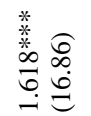

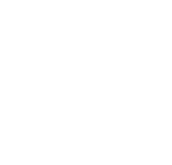

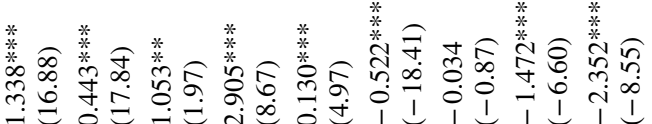

$$
\begin{aligned}
& -0-i \text { i过 }
\end{aligned}
$$

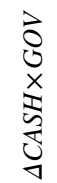

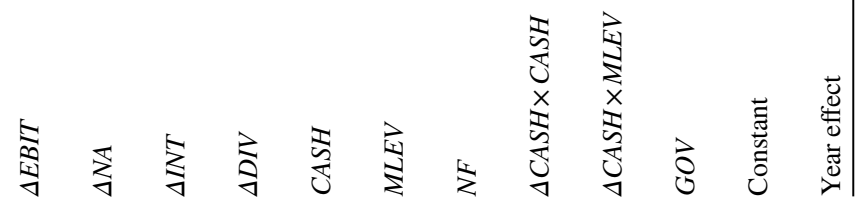$$
\text { Ð }
$$ 


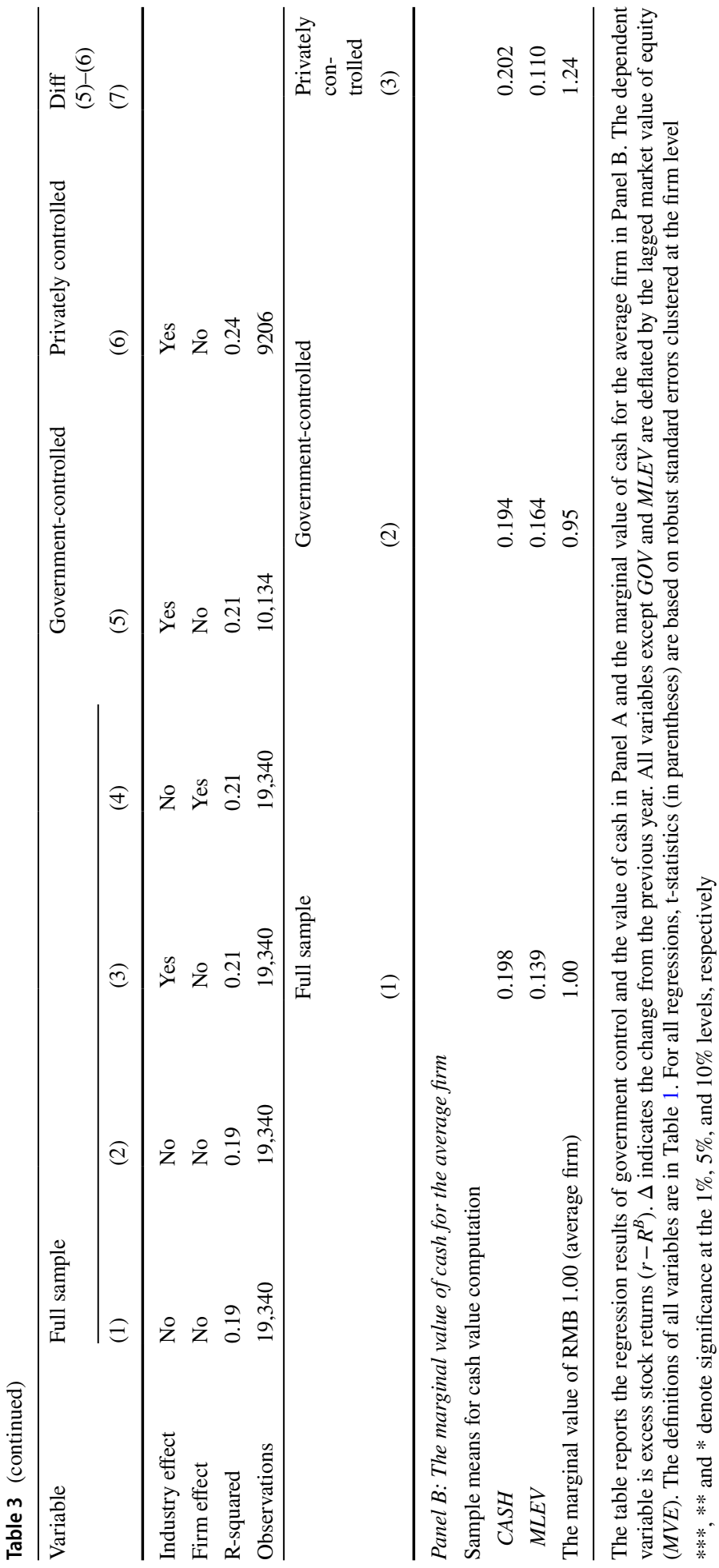




\subsection{Robustness tests}

\subsubsection{Endogeneity concern}

In the earlier analysis, we have attempted to mitigate the endogeneity concern using fixed effect regressions by controlling for year, industry, or firm heterogeneity, which may alleviate the omitted-variable bias. Our main result is interpreted based on the coefficients on the interaction between government control and the change in cash. Cash holdings may change substantially over time, but government control may stay relatively stable. Therefore, if endogeneity exists, it tends to affect the coefficient of government control rather than its interaction with the change in cash (Dittmar and Mahrt-Smith 2007). Nevertheless, we now conduct several additional analyses to further address the possible endogeneity concern, as shown below.

First, we use the lagged variable on government control. It is not likely that the lagged government control is endogenously determined with the current excess stock return. As shown in column 1 of Table 4, the main result remains qualitatively unchanged. Our result is also robust using the 2- and 3-year lagged variables on government control.

Second, to control for observable differences in firm and industry attributes, we next perform the analysis based on a propensity-score matched sample. We first run a logit model regressing the likelihood of a given firm to be controlled by the government on firm size, firm age, book-to-market ratio, leverage, return on assets, and year and industry effects. Then, the likelihood (i.e. the propensity score) that a firm is government-controlled is estimated. Each observation in the government-controlled group is matched to an observation in the privately controlled group based on the nearest neighbor technique. We allow for replacement and require the difference in the propensity scores for each pair to be within $0.1 \%$ in absolute value. Our final sample comprises 19,594 firm-year observations, with 9797 firm-years being controlled by the government and the remaining 9797 firmyears by private owners. ${ }^{6}$ The result of using the matched sample is shown in column 2 of Table 4. As evident, the negative impact of government control on the value of cash still holds.

Finally, we perform an analysis focusing on firms that have undergone through changes in their type of ultimate controlling from the state to private owners during the sample period, as such a shift may lead to a decrease in agency costs (or an increase in financial constraints) that may affect the value of cash. To validate our main finding, reported earlier, we expect to observe a positive impact of such a move on the value of cash. During our sample period, a total of 187 firms have experienced such transformation, and an indicator, Transfer, is constructed such that it is equal to one in the year when the firm is transferred to private ownership and afterwards, and zero in years preceding the transformation. We re-estimate Eq. (1) by replacing government control $(G O V)$ with the indicator variable, Transfer, and report the result in column 3, which shows a significant increase in the value of cash following such a transformation from government control into private hands, verifying our main finding - that government control does reduce the value of cash.

\footnotetext{
6 The number of observations for the matched sample increases to 19,594 since we allow for replacement, i.e. we allow a firm in the control group (i.e. privately controlled firms) to be matched with two or more firms in the treated group (i.e. government-controlled firms).
} 
Table 4 Addressing endogenous concern

\begin{tabular}{|c|c|c|c|}
\hline & $\begin{array}{l}\text { Lagged government } \\
\text { control } \\
\text { (1) }\end{array}$ & (2) & (3) \\
\hline$\triangle C A S H$ & $\begin{array}{l}1.892 * * * \\
(17.18)\end{array}$ & $\begin{array}{l}1.770 * * * \\
(10.04)\end{array}$ & $\begin{array}{l}1.291 * * * \\
(4.67)\end{array}$ \\
\hline$\triangle C A S H \times G O V$ & $\begin{array}{l}-0.285^{* * * *} \\
(-3.37)\end{array}$ & $\begin{array}{l}-0.403 * * * \\
(-3.51)\end{array}$ & \\
\hline$\triangle C A S H \times$ Transfer & & & $\begin{array}{l}0.639 * * * \\
(3.24)\end{array}$ \\
\hline$\triangle E B I T$ & $\begin{array}{l}1.451 * * * \\
(17.00)\end{array}$ & $\begin{array}{l}1.348^{* * * *} \\
(10.72)\end{array}$ & $\begin{array}{l}1.074 * * * \\
(5.63)\end{array}$ \\
\hline$\triangle N A$ & $\begin{array}{l}0.471 * * * \\
(17.98)\end{array}$ & $\begin{array}{l}0.430 * * * \\
(9.86)\end{array}$ & $\begin{array}{l}0.498 * * * \\
(6.92)\end{array}$ \\
\hline$\Delta I N T$ & $\begin{array}{l}0.983^{*} \\
(1.72)\end{array}$ & $\begin{array}{l}0.324 \\
(0.31)\end{array}$ & $\begin{array}{l}-0.647 \\
(-0.38)\end{array}$ \\
\hline$\Delta D I V$ & $\begin{array}{l}2.867 * * * \\
(7.98)\end{array}$ & $\begin{array}{l}2.426 * * * \\
(3.85)\end{array}$ & $\begin{array}{l}2.275^{* * *} \\
(2.30)\end{array}$ \\
\hline $\mathrm{CASH}$ & $\begin{array}{l}0.181 * * * \\
(6.39)\end{array}$ & $\begin{array}{l}0.059 \\
(1.30)\end{array}$ & $\begin{array}{l}0.135 \\
(1.57)\end{array}$ \\
\hline$M L E V$ & $\begin{array}{l}-0.616^{* * * *} \\
(-20.05)\end{array}$ & $\begin{array}{l}-0.555^{* * * *} \\
(-11.59)\end{array}$ & $\begin{array}{l}-0.683^{* * * *} \\
(-7.69)\end{array}$ \\
\hline$N F$ & $\begin{array}{l}-0.024 \\
(-0.59)\end{array}$ & $\begin{array}{l}0.041 \\
(0.64)\end{array}$ & $\begin{array}{l}0.010 \\
(0.08)\end{array}$ \\
\hline$\triangle C A S H \times C A S H$ & $\begin{array}{l}-1.436^{* * * *} \\
(-6.47)\end{array}$ & $\begin{array}{l}-1.292 * * * \\
(-3.99)\end{array}$ & $\begin{array}{l}-2.029 * * * \\
(-4.40)\end{array}$ \\
\hline$\triangle C A S H \times M L E V$ & $\begin{array}{l}-2.450 * * * \\
(-8.52)\end{array}$ & $\begin{array}{l}-1.856^{* * * *} \\
(-3.81)\end{array}$ & $\begin{array}{l}-2.582 * * * \\
(-3.48)\end{array}$ \\
\hline$G O V$ & $\begin{array}{l}-0.016^{* *} \\
(-1.98)\end{array}$ & $\begin{array}{l}-0.042^{* * * *} \\
(-3.88)\end{array}$ & \\
\hline Transfer & & & $\begin{array}{l}0.048 * * \\
(2.03)\end{array}$ \\
\hline Constant & $\begin{array}{l}-0.021 \\
(-0.81)\end{array}$ & $\begin{array}{l}-0.078^{* *} \\
(-2.44)\end{array}$ & $\begin{array}{l}-0.045^{*} \\
(-1.66)\end{array}$ \\
\hline Year effect & Yes & Yes & Yes \\
\hline Industry effect & Yes & Yes & Yes \\
\hline R-squared & 0.22 & 0.27 & 0.25 \\
\hline Observations & 18,285 & 19,594 & 2208 \\
\hline
\end{tabular}

The table reports the results of addressing endogeneity concerns. The dependent variable is excess stock returns $\left(r-R^{B}\right) . \Delta$ indicates the change from the previous year. All variables except GOV, Transfer, and $M L E V$ are deflated by the lagged market value of equity $(M V E)$. The definitions of all variables are in Table 1. For all regressions, t-statistics (in parentheses) are based on robust standard errors clustered at the firm level

$* * *, * *$ and $*$ denote significance at the $1 \%, 5 \%$, and $10 \%$ levels, respectively 


\subsubsection{Alternative measures of government control and the expected change in cash}

To evaluate the sensitivity of our main finding, we re-estimate Eq. (1) using three alternative measures of government control. The first two, GOV1 and GOV2, are dummies with $10 \%$ and $20 \%$ cut-offs of ultimate control right, respectively, and the third, GOV_cont, is a continuous measure of government control using ultimate control right. The results are reported in columns $1-3$ in Table $5 .^{7}$ We find that our main prediction related to government control remains unaffected: The coefficient on the interaction term $\triangle C A S H \times G O V$ is negative in all three columns, and is statistically significant at the $1 \%$ level for both GOVI and GOV2, and at the $10 \%$ level for GOV_cont.

Moving to our key independent variable, the change in cash is defined as the unexpected change in cash holdings. The results reported thus far assume that the expected change in cash is equal to zero, and therefore, the change in cash is, in fact, the realized change in cash. Consistent with Faulkender and Wang (2006), we now conduct robustness checks using three alternative definitions to measure the expected change in cash, as shown below.

The first measure is the average change in cash of the corresponding benchmark portfolio over the year (Portf. Ave). It follows that if most firms in the same size and book-tomarket portfolio change cash reserves over the year, such change should be reflected in the benchmark return already, and the excess return is one that is not revealed in the benchmark return. With respect to two other measures, we adopt two models from Almeida et al. (2004) to obtain the expected change in cash. In both cases, changes in cash are regressed on factors that represent sources and uses of cash. The unexpected change in cash is measured as the difference between the actual change in cash and the predicted change in cash from the models (i.e. residuals). The first model, ACW (1), is as follows:

$$
\Delta C A S H_{i, t}=\alpha_{0}+\alpha_{1} C F_{i, t-1}+\alpha_{2} M B_{i, t-1}+\alpha_{3} S I Z E_{i, t-1}+\varepsilon_{i, t}
$$

where $\triangle C A S H$ is the change in cash and cash equivalents, $C F$ is cash flow, $M B$ is marketto-book ratio and $S I Z E$ is firm size. All variables are deflated by the lagged market value of equity, except for the market-to-book ratio $(M B)$ and firm size $(S I Z E)$.

The second model, $\mathrm{ACW}(2)$, adds capital expenditures (CAPEX), change in net working capital $(\triangle N W C)$ and change in short-term debt $(\triangle S T D)$, all lagged deflated by the lagged market value of equity, as additional explanatory variables. The equation is shown below:

$$
\begin{aligned}
\Delta \text { CASH }_{i, t}= & \alpha_{0}+\alpha_{1} C F_{i, t-1}+\alpha_{2} M B_{i, t-1}+\alpha_{3} S_{I Z E_{i, t-1}}+\alpha_{4} C A P E X_{i, t-1}+\alpha_{5} \Delta N W C_{i, t-1} \\
& +\alpha_{6} \Delta S T D_{i, t-1}+\varepsilon_{i, t}
\end{aligned}
$$

The results are shown in columns 4-6 of Table 5. The expected change in cash is measured as the portfolio average in column 4, ACW (1) in column 5 and ACW (2) in column 6. Overall, using different measurements for the expected change in cash generates nearly identical results to those reported in Table 3, consistent with Hypothesis 1, that government control reduces investors' valuation of cash held by firms.

\footnotetext{
${ }^{7}$ To save space, the control variables are not reported in this and following tables, but they are available upon request.
} 


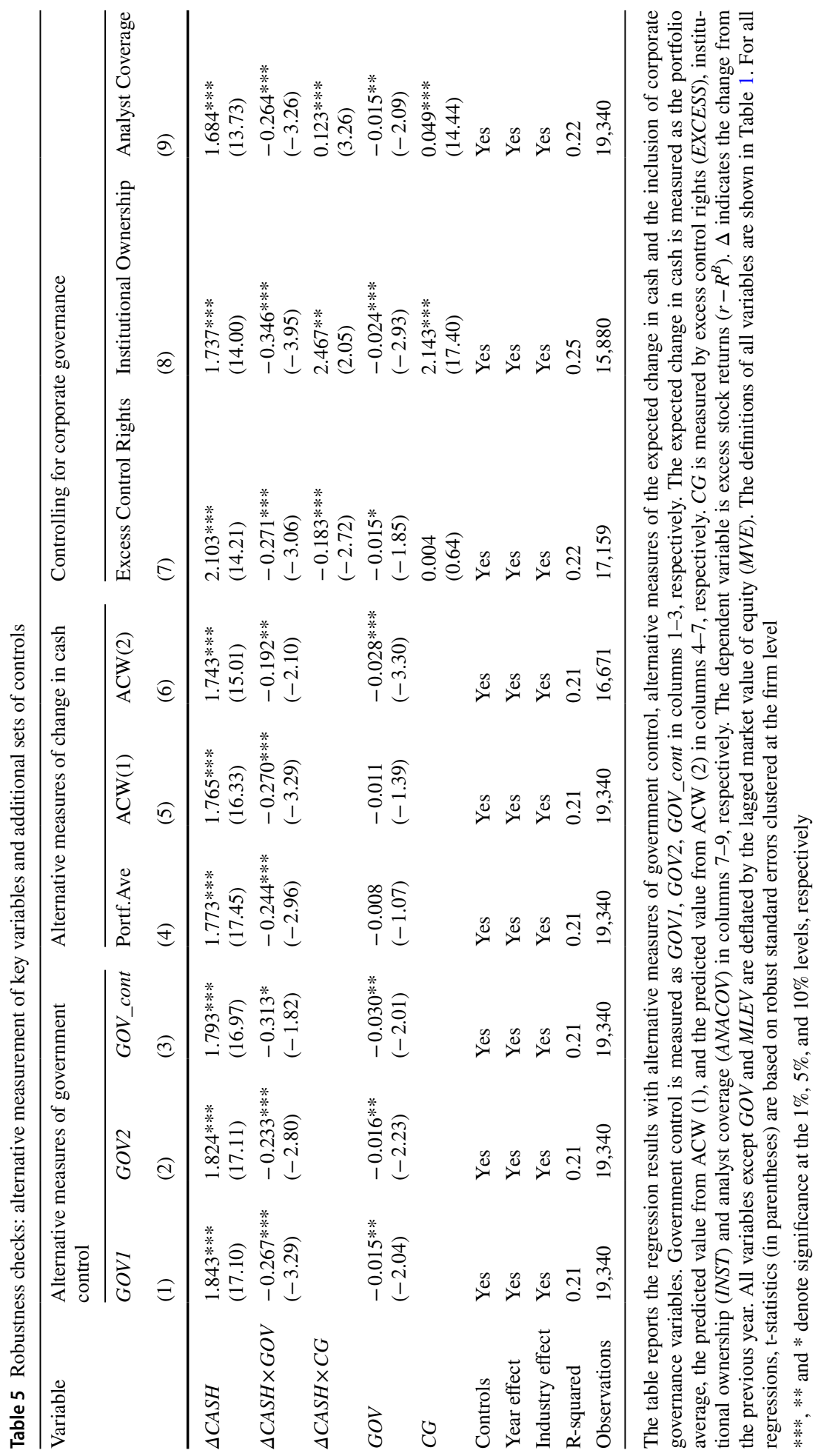




\subsubsection{Controlling for corporate governance}

To reduce the concern about potential correlated omitted variables, we further examine whether our main finding is sensitive to the inclusion of corporate governance variables. Three proxies are considered from the aspects of excess control rights, institutional ownership and analyst coverage. First, the ratio of control rights to cash-flow rights by the ultimate controllers is used to measure excess control rights (Lemmon and Lins 2003; Xu et al. 2016). We use $10 \%$ as the cut-off point to determine effective control at the ultimate level (Claessens et al. 2002). Large excess control rights entrench the controlling shareholders and give them the ability to tunnel, while small cash-flow rights limit controlling shareholders' wealth losses from the tunneling. Thus, firms with more excess control rights are worse governed.

Second, we follow Firth et al. (2016) and define institutional ownership (INST) as the percentage of shares owned by domestic mutual funds and qualified foreign institutional investors (QFII). Compared with other institutional investors, such as banks, insurance and securities companies, domestic mutual funds and QFII have a higher exit threat and thus are more active and effective in monitoring. Finally, analyst coverage (ANACOV) is measured as the natural logarithm of one plus the number of analysts following the firm (Feng et al. 2016). Analyst coverage plays an important monitoring role in reducing earnings management and managerial expropriation (Yu 2008; Chen et al. 2015). Each of the three governance variables and their interactions with the change in cash is added into Eq. (1) one by one. The results are reported in columns 7-9 of Table 5. Consistent with prior literature, firms with low excess control rights, high institutional ownership and high analyst coverage have a higher value of cash. Significantly, the negative impact of government control on the value of cash still exists, which is above and beyond the impact of corporate governance. ${ }^{8}$

\subsection{Why does government control lead to a lower value of cash?}

As discussed earlier, the negative impact of government control on the value of cash may arise from two possible channels: One is from the high agency costs associated with political objectives and managerial interests due to poor governance mechanisms, which we refer to as agency costs of political expropriation channel, and another is through low financial constraints inherited in firms under government control due to preferential access to credit provided by the government, which we refer to as financial constraints of the soft-budget effect channel. In this section, we investigate mechanisms through which the government control reduces the value of cash. Specifically, we examine how government affects a firm's dissipation of cash holdings, financial constraints and external financing channels.

\subsubsection{Government control and dissipation of cash holdings}

According to the agency costs channel, cash holdings can be easily diverted by corporate insiders to be used in projects in accordance with political considerations, such as

\footnotetext{
${ }^{8}$ In considering that our results may be affected by changes in regulations and institutional development during the sample period, we identify two important events-the split share structure reform and the anticorruption campaign - and incorporate these two events into model specification. Our findings suggest that the negative impact of government control on the value of cash still holds. We would like to thank one of the referees for raising this point, and the results are available upon request.
} 
increasing employment rate and maintaining social stability and gaining national pride, rather than project merits. With poor monitoring systems, managers in government-controlled firms are entrenched and may use free cash flows to overinvest in empire-building (Jensen and Meckling 1976). In line with the free cash flow hypothesis, prior studies find that excess cash and week governance schemes lead to increases in capital expenditure (Iskandar-Datta and Jia 2014). The agency costs of political expropriation channel predict that firms under government control may increase the use of cash in subsequent investments, especially those with low investment efficiency (Jaslowitzer et al. 2016; Chen et al. 2017). In contrast, if the financial constraints channel holds, firms under government control may face a lower degree of financial constraints and have better access to external financing, such as bank loans, and they are less likely to use internal finance, such as cash, for investments (Denis and Sibilkov 2009). Therefore, the financial constraints channel suggests that government control is less associated with the use of cash holdings in subsequent investment.

We test this premise by following Gao et al. (2013) to estimate a logit regression with the dependent variable being the increase in investment (INCR_INV), a dummy variable that takes value of one if a firm increases investment in the next year, and zero otherwise. The impact of government control on the use of cash in subsequent investment is indicated by the coefficient on the interaction between cash and government control ( $C A S H \times G O V)$. The agency costs (or financial constraints) channel implies that firms under government control are more (less) likely to increase the use of cash in subsequent investment, that is, a positive (negative) coefficient on the interaction. Controlling variables include Tobin's Q $(Q)$, firm size $(S I Z E)$, cash flow $(C F)$, book leverage $(B L E V)$, dividend dummy $(D I V)$, sales growth $(S G)$ and return on asset $(R O A)$. The results are shown in Table 6, where investment is measured as capital expenditure in column 1, and the sum of capital expenditure and acquisitions in column 2. As evident, the coefficient on the interaction term between cash and government control is positive and statistically significant in both columns, supporting the agency costs channel, that firms with government control disgorge more cash via investments compared with privately controlled firms.

Next, we investigate whether firms with government control use cash to invest in projects associated with corporate innovation. The rationale of conducting this test is that if firms with government control invest in projects for political objectives, cash is less likely to be employed in innovation activities, such as R\&D. The agency costs of political expropriation predict a negative relationship between cash and $R \& D$ in firms under government control, while the financial constraints of the soft-budget effect channel predicts no such relationship. To test for this, we define the increase in $\mathrm{R} \& \mathrm{D}\left(I N C R \_R D\right)$ as a dummy variable that is equal to one if a firm increases $\mathrm{R} \& \mathrm{D}$ in the next year, and zero otherwise. ${ }^{9}$ The result is shown in column 3, where the coefficient on the interaction term $C A S H \times G O V$ is negative and statistically significant, confirming our conjecture that firms under government control are less likely to disgorge cash via innovation activities.

Finally, we test for the impact of government control on investment efficiency. The extant literature suggests that firms with government control may be obligated to invest in politically favored projects that are unprofitable, leading to investment inefficiency (Chen et al., 2011b). The agency costs channel suggests a negative impact of government control on investment efficiency, while the financial constraints channel does not. We follow Chen

\footnotetext{
9 Since R\&D data is only available from year 2007, observations in column 3 of Table 5 therefore reduce to 12,532 .
} 
Table 6 Disgorging cash via investment and investment efficiency

\begin{tabular}{|c|c|c|c|c|c|}
\hline \multirow[t]{2}{*}{ Variable } & \multicolumn{2}{|c|}{ Increase in Investment } & \multirow{2}{*}{$\begin{array}{l}\text { Increase in } R \& D \\
\text { (3) }\end{array}$} & \multicolumn{2}{|l|}{ Investment } \\
\hline & (1) & (2) & & (4) & (5) \\
\hline$G O V$ & $\begin{array}{l}-0.054 \\
(-1.10)\end{array}$ & $\begin{array}{l}-0.037 \\
(-0.75)\end{array}$ & $\begin{array}{l}-0.136 \\
(-1.37)\end{array}$ & $\begin{array}{l}-0.004 * \\
(-1.90)\end{array}$ & $\begin{array}{l}-0.005^{* *} \\
(-2.07)\end{array}$ \\
\hline $\mathrm{CASH}$ & $\begin{array}{l}0.809 * * * \\
(5.19)\end{array}$ & $\begin{array}{l}0.985 * * * \\
(6.16)\end{array}$ & $\begin{array}{l}1.224 * * * \\
(4.52)\end{array}$ & & \\
\hline$C A S H \times G O V$ & $\begin{array}{l}0.629 * * * \\
(2.73)\end{array}$ & $\begin{array}{l}0.584 * * \\
(2.48)\end{array}$ & $\begin{array}{l}-0.883^{* *} \\
(-2.10)\end{array}$ & & \\
\hline$Q \times G O V$ & & & & $\begin{array}{l}-0.002 \text { **** } \\
(-2.59)\end{array}$ & $\begin{array}{l}-0.003 * * * \\
(-3.75)\end{array}$ \\
\hline$Q$ & $\begin{array}{l}0.017 \\
(1.29)\end{array}$ & $\begin{array}{l}0.011 \\
(0.87)\end{array}$ & $\begin{array}{l}0.032 \\
(1.50)\end{array}$ & $\begin{array}{l}0.003 * * * \\
(5.53)\end{array}$ & $\begin{array}{l}0.005 * * * \\
(8.06)\end{array}$ \\
\hline SIZE & $\begin{array}{l}0.004 \\
(0.23)\end{array}$ & $\begin{array}{l}-0.003 \\
(-0.15)\end{array}$ & $\begin{array}{l}0.022 \\
(0.64)\end{array}$ & $\begin{array}{l}0.001 \\
(1.54)\end{array}$ & $\begin{array}{l}0.002 * * \\
(2.26)\end{array}$ \\
\hline$C F$ & $\begin{array}{l}0.077 \\
(0.34)\end{array}$ & $\begin{array}{l}-0.202 \\
(-0.90)\end{array}$ & $\begin{array}{l}-0.560 \\
(-1.52)\end{array}$ & $\begin{array}{l}0.101 * * * \\
(14.48)\end{array}$ & $\begin{array}{l}0.102 * * * \\
(13.85)\end{array}$ \\
\hline$B L E V$ & $\begin{array}{l}-0.398 * * * \\
(-3.57)\end{array}$ & $\begin{array}{l}-0.441 * * * \\
(-3.94)\end{array}$ & $\begin{array}{l}-0.138 \\
(-0.62)\end{array}$ & $\begin{array}{l}0.063 * * * \\
(13.11)\end{array}$ & $\begin{array}{l}0.065 * * * \\
(13.21)\end{array}$ \\
\hline$D I V$ & $\begin{array}{l}-0.077 * * \\
(-2.13)\end{array}$ & $\begin{array}{l}-0.077 * * \\
(-2.12)\end{array}$ & $\begin{array}{l}0.510 * * * \\
(8.08)\end{array}$ & $\begin{array}{l}0.017 * * * \\
(14.57)\end{array}$ & $\begin{array}{l}0.018 * * * \\
(14.84)\end{array}$ \\
\hline$S G$ & $\begin{array}{l}0.146^{* * * *} \\
(2.67)\end{array}$ & $\begin{array}{l}0.076 \\
(1.37)\end{array}$ & $\begin{array}{l}0.454 * * * \\
(5.65)\end{array}$ & $\begin{array}{l}0.008 * * * \\
(6.04)\end{array}$ & $\begin{array}{l}0.0014 * * * \\
(9.08)\end{array}$ \\
\hline$R O A$ & $\begin{array}{l}2.747 * * * \\
(7.87)\end{array}$ & $\begin{array}{l}2.904 * * * \\
(8.26)\end{array}$ & $\begin{array}{l}3.014 * * * \\
(5.15)\end{array}$ & $\begin{array}{l}0.040 * * * \\
(3.88)\end{array}$ & $\begin{array}{l}0.035 * * * \\
(3.23)\end{array}$ \\
\hline Constant & $\begin{array}{l}-0.305 \\
(-0.85)\end{array}$ & $\begin{array}{l}-0.146 \\
(-0.40)\end{array}$ & $\begin{array}{l}-3.693 * * * \\
(-5.03)\end{array}$ & $\begin{array}{l}0.012 \\
(0.76)\end{array}$ & $\begin{array}{l}-0.005 \\
(-0.32)\end{array}$ \\
\hline Year effects & Yes & Yes & Yes & Yes & Yes \\
\hline Industry effects & Yes & Yes & Yes & Yes & Yes \\
\hline Pseudo R-squared & 0.02 & 0.02 & 0.28 & 0.16 & 0.16 \\
\hline Observations & 16,682 & 16,682 & 12,532 & 19,321 & 19,321 \\
\hline
\end{tabular}

The table reports the results of disgorging cash via investment, R\&D, and investment efficiency where Investment is measured as capital expenditure in columns 1 and 4, the sum of capital expenditure and acquisitions in columns 2 and 5. The dependent variable is the increase in investment (INCR_INV) in columns 1 and 2, the increase in R\&D (INCR_RD) in column 3 and investment in columns 4 and 5. CASH and CF are deflated by total assets. The definitions of all variables are shown in Table 1. For all regressions, t-statistics (in parentheses) are based on robust standard errors clustered at the firm level

$* * *, * *$ and $*$ denote significance at the $1 \%, 5 \%$, and $10 \%$ levels, respectively

et al (2011b) and use the sensitivity of investment expenditure to investment opportunities (Tobin's Q) as a measure of investment efficiency. Results are reported in columns 4 and 5 of Table 6. The results indicate that the coefficient on the interaction term, $\mathrm{Q} \times G O V$, is negative and highly significant when investment is measured as capital expenditure (column 4), the sum of capital expenditure and acquisitions (column 5). The negative impact of government control on the efficiency of investment further supports the agency costs of political expropriation associated with government control.

Taken together, the results reported in Table 6 support the agency costs of political expropriation channel in that the state uses corporate cash under its control to invest in 
projects that mainly achieve political objectives, with less concerns on innovation and investment efficiency, leading to a lower value of cash for firms controlled by the government than by private owners. Our finding is consistent with Chen et al. (2011b) and Chen et al. (2017), who demonstrate that the government control distorts firm investment behavior and harms investment efficiency. Similar, Jaslowitzer et al. (2016) find that state ownership restrains firms' responsiveness to investment opportunities, and Boubakri et al. (2013a) contend that state ownership is negatively associated with corporate risk-taking.

\subsubsection{Financial constraints and external financing channels}

The evidence provided earlier suggests that the negative impact of government control on the value of cash is through agency costs of political expropriation. In this section, we conduct several direct tests showing that firms under government control may not be necessarily subject to the financial constraints of the soft-budget effect. Specifically, if the financial constraints channel is valid, government control should be expected to enhance corporate external financing ability and alleviate financial constraints. We measure the degree of financial constraints using cash flow sensitivity of cash, based on two models developed by Almeida et al. (2004), ${ }^{10}$ and external financing using gross equity issuance and net debt issuance, based on the model adopted by Firth et al. (2012). The financial constraints channel suggests a negative impact of government control on cash flow sensitivity of cash and a positive impact of government control on equity and debt issuances. The results for the cash flow sensitivity of cash are presented in columns 1 and 2 of Table 7 . It shows clearly that the coefficient on the interaction term between the government control and cash flow $(G O V \times C F)$ is not statistically significant in both cases, confirming our premise that firms under government control are not particularly subject to soft-budget on financial constraints compared to firms under private control. In terms of external financing for gross equity issuance and net debt issuance, shown in columns 3 and 4, respectively, the coefficient on government control is negative in both cases; statistically significant for gross equity issuance; and marginally significant for net debt issuance, implying that government control has, in fact, a negative impact on external financing. Overall, our results are consistent with recent literature, suggesting that government control does not necessarily enhance financing ability or mitigate financial constraints (Ben-Nasr et al. 2012; Firth et al. 2012; Borisova et al. 2015; Jaslowitzer et al. 2016).

Based on the evidence provided in this section, we conclude that the negative impact of government control on the value of cash is solely due to the severe agency costs related to the political expropriation, rather than financial constraints of the softbudget effect.

\footnotetext{
${ }^{10}$ Compared with traditional measures of financial constraints, such as investment-cash flow sensitivity, cash flow sensitivity of cash can mitigate the concern of a noisy measure of Tobin's Q. The intuition of this measure is that firms with financial constraints should increase their holdings of cash from cash flow to respond to future unexpected changes. The effect of financial constraints is captured by a positive sensitivity of cash flow to cash.
} 
Table 7 Government control, financial constraints and external financing channels

\begin{tabular}{|c|c|c|c|c|}
\hline \multirow[t]{3}{*}{ Variable } & \multirow{2}{*}{\multicolumn{2}{|c|}{$\frac{\text { Financial constraints }}{\Delta C A S H}$}} & \multicolumn{2}{|c|}{ External financing channels } \\
\hline & & & \multirow{2}{*}{$\begin{array}{l}G E I \\
\text { (3) }\end{array}$} & \multirow{2}{*}{$\begin{array}{l}N D I \\
(4)\end{array}$} \\
\hline & (1) & (2) & & \\
\hline GOV & $\begin{array}{l}0.009 * * * \\
(5.43)\end{array}$ & $\begin{array}{l}0.003 * \\
(1.79)\end{array}$ & $\begin{array}{l}-0.011 \text { *** } \\
(-7.25)\end{array}$ & $\begin{array}{l}-0.003^{*} \\
(-1.72)\end{array}$ \\
\hline$C F$ & $\begin{array}{l}0.302 * * * \\
(17.82)\end{array}$ & $\begin{array}{l}0.312 * * * \\
(18.71)\end{array}$ & & \\
\hline$G O V \times C F$ & $\begin{array}{l}-0.025 \\
(-1.18)\end{array}$ & $\begin{array}{l}0.010 \\
(0.50)\end{array}$ & & \\
\hline$M B$ & $\begin{array}{l}0.006 * * * \\
(8.19)\end{array}$ & $\begin{array}{l}0.006 \text { **** } \\
(8.89)\end{array}$ & $\begin{array}{l}-0.001 * * \\
(-1.97)\end{array}$ & $\begin{array}{l}0.007 * * * \\
(7.57)\end{array}$ \\
\hline SIZE & $\begin{array}{l}0.013 * * * \\
(18.30)\end{array}$ & $\begin{array}{l}0.012 * * * \\
(19.11)\end{array}$ & $\begin{array}{l}0.007 * * * \\
(9.95)\end{array}$ & $\begin{array}{l}0.012 * * * \\
(12.01)\end{array}$ \\
\hline CAPEX & & $\begin{array}{l}-0.412 * * * \\
(-29.29)\end{array}$ & & \\
\hline$\triangle N W C$ & & $\begin{array}{l}-0.207 * * * \\
(-19.46)\end{array}$ & & \\
\hline$\triangle S T D$ & & $\begin{array}{l}0.188^{* * * *} \\
(13.71)\end{array}$ & & \\
\hline$R O A$ & & & $\begin{array}{l}0.017^{*} \\
(1.75)\end{array}$ & $\begin{array}{l}0.046 * * * \\
(3.14)\end{array}$ \\
\hline$B L E V$ & & & $\begin{array}{l}-0.022 * * * \\
(-4.96)\end{array}$ & $\begin{array}{l}0.282 * * * \\
(38.01)\end{array}$ \\
\hline$A G E$ & & & $\begin{array}{l}0.003 * * \\
(2.40)\end{array}$ & $\begin{array}{l}-0.030 \text { *** } \\
(-20.21)\end{array}$ \\
\hline Constant & $\begin{array}{l}-0.302 * * * \\
(-19.14)\end{array}$ & $\begin{array}{l}-0.266 * * * \\
(-18.78)\end{array}$ & $\begin{array}{l}-0.126 * * * \\
(-8.19)\end{array}$ & $\begin{array}{l}-0.232 * * * \\
(-11.10)\end{array}$ \\
\hline Year effects & Yes & Yes & Yes & Yes \\
\hline Industry effects & Yes & Yes & Yes & Yes \\
\hline R-squared & 0.14 & 0.28 & 0.03 & 0.21 \\
\hline Observations & 16,636 & 16,636 & 16,636 & 16,636 \\
\hline
\end{tabular}

The table reports the results of government control, financial constraints, and external financing channels. The dependent variable is the change in cash $(\triangle C A S H)$ in columns 1 and 2, gross equity issuance $(G E I)$ in column 3 and net debt issuance $(N D I)$ in column 4. $\Delta$ indicates the change from the previous year. All variables except $G O V, S I Z E$, and $A G E$ are deflated by total assets. The definitions of all variables are shown in Table 1. For all regressions, t-statistics (in parentheses) are based on robust standard errors clustered at the firm level

$* * *, * *$ and $*$ denote significance at the $1 \%, 5 \%$, and $10 \%$ levels, respectively

\section{The role of institutional development}

Prior literature on cross-country analysis indicates that firms with close ties to governments benefit more from political connections in countries with poor institutional development (Faccio 2006; Boubakri et al. 2012, 2013b). In terms of China, government control may be associated with more government-related contracts, fewer industry competitors and more growth opportunities (i.e. "helping hand"), especially in less developed regions due to a series of subsidization programs adopted to develop the local economy in recent years, 
which may alleviate the agency conflicts of political objectives and entrenched managers. We test for this premise using a wide range of measures to proxy for market development and local government condition, which may affect the relationship between government control and value of cash. We expect that the negative impact of government control on the value of cash is mitigated in regions with low market development and poor government condition, where the benefits of government control dominate the costs of government control.

A number of indices, which are widely used in prior literature, are utilized to measure province-level institutional development (Firth et al. 2009; Chen et al. 2011a). First, the three measures of market development are: the overall market development $(M K T)$; the liberalization of the banking sector $(B A N K)$; and government decentralization in the economy $(G O V T)$. All three measures are relative ranking indices compiled from the National Economic Research Institute (NERI) under the auspices of the China Reform Foundation (Fan et al. 2011; Wang et al. 2017). The indices for the period 2003-2007 are collected from the NERI 2011 report (Fan et al. 2011), and those for the period 2008-2015 are extracted from the NERI 2016 report (Wang et al. 2017). ${ }^{11}$ Since the indices from the two reports are calculated on different base years (base year is 1997 for the NERI 2011 report and 2008 for the NERI 2016 report), we cannot use the values of the four indices directly. Instead, we focus on the ranking of provinces by each of the indices in each year.

In addition, we adopt use three proxies to measure local government and employment conditions, including the government overall fiscal condition (FISC), the government nonarbitrary revenue $(N A D M)$ and employment conditions $(E M P)$. FISC is the ratio of local government revenue to expense, and $N A D M$ is the percentage of local government nonadministrative revenue. EMP is one minus the unemployment rate. The data is extracted from the National Bureau of Statistics (NBS) of China. As argued by Chen et al. (2011a) and Cheung et al. (2010), regions with lower unemployment rates and less fiscal deficits and arbitrary revenues by local governments are more developed.

For each year, we divide our sample firms into two groups according to the median ranking or value of each institutional variable - firms with low/high market development and firms with poor/good government condition - and insert the institutional variable one by one to re-estimate our baseline model Eq. (1). We also add gross regional product (GRP) and its growth rate $(G R P G R T H)$ to control for regional differences. The results are reported in Table 8. Consistent with our expectation, the negative impact of government control on the value of cash is more pronounced in regions with high market development as shown in columns 2, 4 and 6, and in regions with good government condition as displayed in columns 8,10 and 12 . The results suggest that in the region with high institutional development, low government control leads to a high market value of cash. In areas that are less developed (columns 1, 3 and 5) and have a weak government condition (columns 7, 9 and 11), the influence of government control on the value of cash is negative, however, but not statistically significant in five out of six cases. This finding can be interpreted such that the agency costs of political expropriation in the highly centralized area may be mitigated to some extent by the government-subsidized development programs, such as the western development strategy launched in late 1990, the north-east revival strategy in 2003 and the

\footnotetext{
11 The NERI 2011 report covers the period 1997-2011, while the NERI 2016 report covers the period 2008-2014. Since the ranking of provinces changes slowly, the data for 2015 is assumed to be the same as that in 2014 in this study. There are a few differences between the two reports. For example, the base years used are different. Some sub-indices are constructed differently. Further details can be found in NERI 2016 report (Wang et al. 2017).
} 


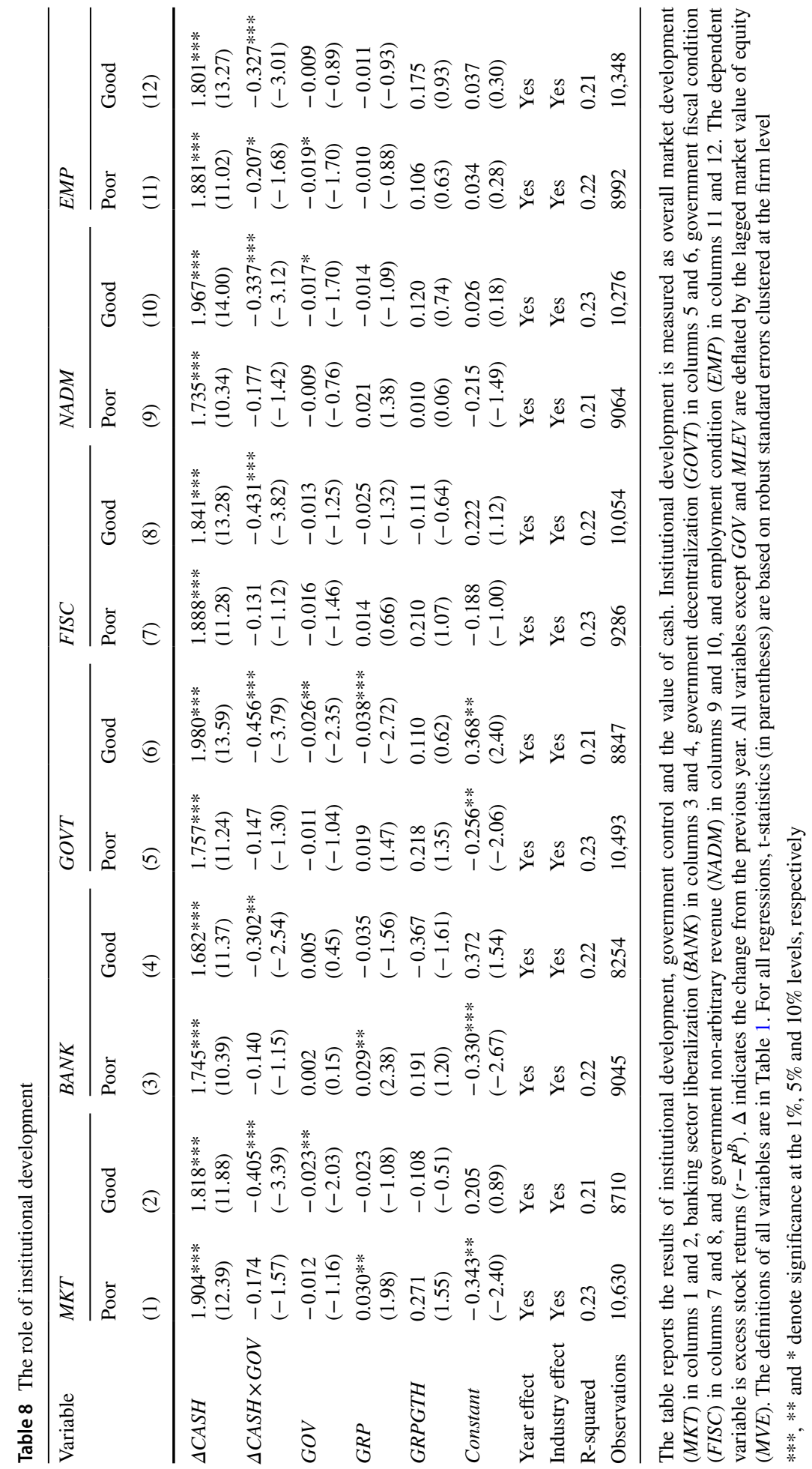


rise of central China in more recent years, in order to improve the disparities of the economic development across the provinces in China. Therefore, it appears that the benefits of government control offset the drawback of agency costs of political objectives, at least to some extent, in these regions. Our finding is largely consistent with Faccio (2006) and Boubakri et al. (2012; 2013b), who demonstrate that firms benefit from close connections to the state and such benefits are generally more pronounced in markets with relatively low institutional development and less efficient legal systems.

\section{Conclusions}

In this paper, we investigate the relationship between government control and the value of cash held by firms. Using a large panel of listed firms in China during the period 2003-2015, we find consistent evidence that government control results in a lower value of cash held by firms. Our finding is robust to the inclusion of year, industry and firm-specific effects, as well as different measures of key variables, and is insensitive to the inclusion of a set of additional control variables. The negative impact of government control on the value of cash remains valid after the endogeneity concerns are addressed carefully by using the lagged government control variable and a propensity-score matching sample, and by focusing on a group of firms that have transferred their ultimate control from government to private owner.

We sought to discover the mechanisms through which government control leads to a lower value of cash by exploring two channels: agency costs of political expropriation and financial constraints of the soft-budget effect. Our results appear to support the former, in that the cash is disgorged more in investment with lower investment efficiency, and less in R\&D expenditure in firms under government control than those under the control of private owners. We find no evidence that either supports government mitigation of financial constraints or enhancement of external financing abilities in listed firms under its control, suggesting that the negative impact of government control on the value of cash does not pertain to financial constraints of the soft-budget effect.

Finally, we find that the negative association between government control and the value of cash depends on regional development. In particular, our empirical evidence shows that this negative impact is mitigated to some extent in regions with low market development. Our finding appears to support the conjecture that the benefits of government control, in association with subsidizing policies, offset the costs of political expropriation in order to improve regional disparity in less developed regions.

Open Access This article is licensed under a Creative Commons Attribution 4.0 International License, which permits use, sharing, adaptation, distribution and reproduction in any medium or format, as long as you give appropriate credit to the original author(s) and the source, provide a link to the Creative Commons licence, and indicate if changes were made. The images or other third party material in this article are included in the article's Creative Commons licence, unless indicated otherwise in a credit line to the material. If material is not included in the article's Creative Commons licence and your intended use is not permitted by statutory regulation or exceeds the permitted use, you will need to obtain permission directly from the copyright holder. To view a copy of this licence, visit http://creativecommons.org/licenses/by/4.0/. 


\section{References}

Acharya VV, Almeida H, Campello M (2007) Is cash negative debt? A hedging perspective on corporate financial policies. J Financ Intermed 16:515-554

Almeida H, Campello M, Weisbach MS (2004) The cash flow sensitivity of cash. J Finance 59:1777-1804

Ben-Nasr H, Boubakri N, Cosset JC (2012) The political determinants of the cost of equity: evidence from newly privatized firms. J Acc Res 50:605-646

Beuselinck C, Cao L, Deloof M, Xia X (2017) The value of government ownership during the global financial crisis. J Corp Finance 42:481-493

Borisova G, Megginson WL (2011) Does government ownership affect the cost of debt? Evidence from privatization. Rev Financ Stud 24:2693-2737

Borisova G, Brockman P, Salas JM, Zagorchev A (2012) Government ownership and corporate governance: evidence from the EU. J Bank Finance 36:2917-2934

Borisova G, Fotak V, Holland K, Megginson WL (2015) Government ownership and the cost of debt: evidence from government investments in publicly traded firms. J Financ Econ 118:168-191

Bortolotti B, Faccio M (2009) Government control of privatized firms. Rev Financ Stud 22:2907-2939

Boubakri N, Cosset JC, Guedhami O (2005) Postprivatization corporate governance: the role of ownership structure and investor protection. J Financ Econ 76:369-399

Boubakri N, Cosset JC, Guedhami O (2008) Privatisation in developing countries: performance and ownership effects. Dev Policy Rev 26:275-308

Boubakri N, Guedhami O, Mishra D, Saffar W (2012) Political connections and the cost of equity capital. J Corp Finance 18:541-559

Boubakri N, Cosset JC, Saffar W (2013a) The role of state and foreign owners in corporate risk-taking: evidence from privatization. J Financ Econ 108:641-658

Boubakri N, Mansi SA, Saffar W (2013b) Political institutions, connectedness, and corporate risk-taking. J Int Bus Stud 44:195-215

Boubakri N, El Ghoul S, Guedhami O, Megginson WL (2018) The market value of government ownership. J Corp Finance 50:44-65

Boycko M, Shleifer A, Vishny RW (1996) A theory of privatisation. Econ J 106:309-319

Charumilind C, Kali R, Wiwattanakantang Y (2006) Connected lending: Thailand before the financial crisis. J Bus 79:181-218

Chen M, Zheng Y (2008) China's regional disparity and its policy responses. China World Econ $16: 16-32$

Chen G, Firth M, Xin Y, Xu L (2008) Control transfers, privatization, and corporate performance: efficiency gains in China's listed companies. J Financ Quant Anal 43:161-190

Chen G, Firth M, Xu L (2009) Does the type of ownership control matter? Evidence from China's listed companies. J Bank Finance 33:171-181

Chen CJ, Li Z, Su X, Sun Z (2011a) Rent-seeking incentives, corporate political connections, and the control structure of private firms: Chinese evidence. J Corp Finance 17:229-243

Chen S, Sun Z, Tang S, Wu D (2011b) Government intervention and investment efficiency: evidence from China. J Corp Finance 17:259-271

Chen T, Harford J, Lin C (2015) Do analysts matter for governance? Evidence from natural experiments. J Financ Econ 115:383-410

Chen R, El Ghoul S, Guedhami O, Wang H (2017) Do state and foreign ownership affect investment efficiency? Evidence from privatizations. J Corp Finance 42:408-421

Cheung YL, Rau PR, Stouraitis A (2010) Helping hand or grabbing hand? Central vs. local government shareholders in Chinese listed firms. Rev Finance 14:669-694

Chou TK, Feng HL (2019) Multiple directorships and the value of cash holdings. Rev Quant Finance Acc 53:663-699

Claessens S, Djankov S, Fan JP, Lang LH (2002) Disentangling the incentive and entrenchment effects of large shareholdings. J Finance 57:2741-2771

Cull R, Xu LC (2003) Who gets credit? The behavior of bureaucrats and state banks in allocating credit to Chinese state-owned enterprises. J Devel Econ 71:533-559

Cull R, Li W, Sun B, Xu LC (2015) Government connections and financial constraints: evidence from a large representative sample of Chinese firms. J Corp Finance 32:271-294

Denis DJ, Sibilkov V (2009) Financial constraints, investment, and the value of cash holdings. Rev Finan Stud 23:247-269

Dittmar A, Mahrt-Smith J (2007) Corporate governance and the value of cash holdings. J Financ Econ 83:599-634 
Faccio M (2006) Politically connected firms. Am Econ Rev 96:369-386

Fama EF, French KR (1993) Common risk factors in the returns on stocks and bonds. J Financ Econ 33:3-56

Fan G, Wang X, Zhu H (2011) NERI index of marketization of China's provinces 2011 report. Economic Science Press, Beijing

Faulkender M, Wang R (2006) Corporate financial policy and the value of cash. J Finance 61:1957-1990

Feng X, Hu N, Johansson AC (2016) Ownership, analyst coverage, and stock synchronicity in China. Int Rev Financ Anal 45:79-96

Firth M, Lin C, Liu P, Wong SM (2009) Inside the black box: bank credit allocation in China's private sector. J Bank Finance 33:1144-1155

Firth M, Malatesta PH, Xin Q, Xu L (2012) Corporate investment, government control, and financing channels: evidence from China's Listed Companies. J Corp Finance 18:433-450

Firth M, Gao J, Shen J, Zhang Y (2016) Institutional stock ownership and firms' cash dividend policies: evidence from China. J Bank Finance 65:91-107

Gao H, Harford J, Li K (2013) Determinants of corporate cash policy: insights from private firms. J Financ Econ 109:623-639

Gordon RH, Li W (2003) Government as a discriminating monopolist in the financial market: the case of China. J Public Econ 87:283-312

Guariglia A, Liu X, Song L (2011) Internal finance and growth: microeconometric evidence on Chinese firms. J Dev Econ 96:79-94

Guedhami O, Pittman JA, Saffar W (2009) Auditor choice in privatized firms: empirical evidence on the role of state and foreign owners. J Acc Econ 48:151-171

Iskandar-Datta ME, Jia Y (2014) Investor protection and corporate cash holdings around the world: new evidence. Rev Quant Finance Acc 43:245-273

Jaslowitzer P, Megginson WL, Rapp MS (2016) Disentangling the effects of state ownership on investment-evidence from Europe. Working paper. Available at SSRN: https://ssrn.com/abstract=27356 98

Jensen MC (1986) Agency costs of free cash flow, corporate finance, and takeovers. Am Econ Rev 76:323-329

Jensen MC, Meckling WH (1976) Theory of the firm: managerial behavior, agency costs and ownership structure. J Financ Econ 3:305-360

Kornai J, Maskin E, Roland G (2003) Understanding the soft budget constraint. J Econ Lit 41:1095-1136

La Porta R, Lopez-de-Silanes F, Shleifer A (1999) Corporate ownership around the world. J Finance 54:471-517

La Porta R, Lopez-de-Silanes F, Shleifer A, Vishny R (2002) Investor protection and corporate valuation. J Finance 57:1147-1170

Lee KW, Lee CF (2009) Cash holdings, corporate governance structure and firm valuation. Rev Pac Basin Financ Mark Policies 12:475-508

Lemmon ML, Lins KV (2003) Ownership structure, corporate governance, and firm value: evidence from the East Asian financial crisis. J Finance 58:1445-1468

Lin HCM, Bo H (2012) State-ownership and financial constraints on investment of Chinese-listed firms: new evidence. Eur J Finance 18:497-513

Liu C, Uchida K, Yang Y (2012) Corporate governance and firm value during the global financial crisis: evidence from China. Int Rev Financ Anal 21:70-80

Megginson WL, Netter JM (2001) From state to market: a survey of empirical studies on privatization. J Econ Lit 39:321-389

Megginson WL, Ullah B, Wei Z (2014) State ownership, soft-budget constraints, and cash holdings: evidence from China's privatized firms. J Bank Finance 48:276-291

Myers SC, Rajan RG (1998) The paradox of liquidity. Quart J Econ 113:733-771

Opler T, Pinkowitz L, Stulz R, Williamson R (1999) The determinants and implications of corporate cash holdings. J Financ Econ 52:3-46

Pinkowitz L, Stulz R, Williamson R (2006) Does the contribution of corporate cash holdings and dividends to firm value depend on governance? A cross-country analysis. J Finance 61:2725-2751

Shleifer A (1998) State versus private ownership. J Econ Perspect 12:133-150

Shleifer A, Vishny RW (1994) Politicians and firms. Quart J Econ 109:995-1025

Shleifer A, Vishny RW (1997) A survey of corporate governance. J Finance 52:737-783

Shleifer A, Vishny RW (1998) The grabbing hand: Government pathologies and their cures. Harvard University Press, Cambridge

Vickers J, Yarrow G (1991) Economic perspectives on privatization. J Econ Perspect 5:111-132 
Wang X, Fan G, Yu J (2017) NERI index of marketization of China's provinces 2016 report. Social Sciences Academic Press (China), Beijing

Xu N, Chen Q, Xu Y, Chan KC (2016) Political uncertainty and cash holdings: evidence from China. J Corp Finance 40:276-295

Yu FF (2008) Analyst coverage and earnings management. J Financ Econ 88:245-271

Publisher's Note Springer Nature remains neutral with regard to jurisdictional claims in published maps and institutional affiliations. 